\title{
How did the publication of the book The Machine That Changed The World change management thinking? Exploring 25 years of lean literature
}

\author{
Dr Donna Samuel \\ Lean Academy, SA Partners, Caerphilly, UK. \\ Dr Pauline Found \\ Buckingham Business School, The University of Buckingham, Buckingham, UK. \\ Dr Sharon J Williams* \\ Cardiff Business School, Cardiff University, Cardiff, UK. \\ *Corresponding author: Williamss78@cardiff.ac.uk
}

\begin{abstract}
Purpose

The purpose of this paper is to take a critical, analytical approach to explore the growth and spread of Lean through the academic and practitioner community over the last twenty-five years to understand the impact of the book The Machine that Changed the World on management thinking.

\section{Design/methodology/approach}

A comprehensive and systematic review of the extant literature of lean was undertaken and analysed critically to observe patterns and trends that could explain the acceptance of Lean as an operations management philosophy. The review spans from 1987 to 2013. To enable us to effectively manage and understand the diffusion of this literature a database, the Lean Publications Database (LPD), was constructed. The number of publications has been adjusted to compensate for growth in the total number of articles published in the same period.
\end{abstract}

\section{Findings}

Lean has evolved to be one of the best-known, yet fiercely debated, process improvement methodologies. It emerged during a proliferation of such methodologies in the business and management literature. Lean has developed from a generic description of Toyota Production System (TPS) to a particular type of organizational and management intervention focused on best practice and process improvement methodologies.

\section{Research limitations/implications}

This paper provides the first comprehensive review of the Lean literature, from the perspective of Lean as the unit of analysis. It covers both sides of the academic debate and categorises the progression of Lean from its origins as a generic description of TPS to a movement that has change management systems in many and diverse sectors.

\section{Practical implications}

This paper demonstrates how Lean research, application and thinking has evolved over 25 years from its origins in Japanese auto-manufacturing to a holistic value system that is applicable to all business sectors, both private and public.

\section{Originality/value}

In most empirical studies on Lean, the unit of analysis is the organisation. In this study, the unit of analysis is the Lean phenomenon itself. This paper examines the impact of The Machine that Changed the World on management thinking. In addition, it presents a step to developing an 
underpinning theory by linking Lean to the Theory of Swift, Even Flow. As such it is of interest to academics in the field of operations management and offers a contribution to knowledge. It is also likely to be of interest to policy makers. Considerable amounts of public money have been spent, and continue to be spent, on promoting Lean. Taxpayers and policymakers are likely to be interested in whether that expenditure is justifiable.

Twenty-five years of publications have been analysed to provide clarity around this popular approach to organisational improvement.

\section{Keywords}

Lean, improvement, literature review, diffusion, Toyota Production System (TPS).

\section{Background and Context}

The term Lean entered the management lexicon via a researcher from the Massachusetts Institute of Technology (MIT), named John Krafcik, working on International Motor Vehicle Programme (IMVP). In Krafcik's (1988) Sloan Management Review article he used the term to describe the Toyota Production System (TPS). The word Lean was selected to capture the essence of the far less resource-hungry TPS compared with typical Western production systems. Though coined by Krafcik, the term Lean is often cited as being made popular by the authors Womack, Jones and Roos (1990) in the influential and best-selling management book entitled The Machine That Changed The World, that came out of the large-scale, five year, five million dollar IMVP study at MIT. Researchers on the programme argue the findings of the study revealed there was a dramatic performance gap between Japanese and Western car producers. The book went on to have far-reaching effects (Oliver et al., 1994; Karlsson and Alhstrom, 1996; Katayama and Bennett, 1996; Benders and Bijsterveld 2000; Lewis, 2000, Bhasin and Burcher, 2006; Shah and Ward, 2007; Holweg, 2007; Tracy and Knight, 2008). The study and the book that came out of it led to the commissioning of two follow-up studies that provided further support for the existence of a substantial performance gap (Anderson, 1992; 1994). These studies were publicised extensively to the manufacturing community at the time.

In The Machine, Womack et al. (1990, p.13) define Lean in terms of its outcomes:

'compared to mass production it uses less of everything - half the human effort in the factory, half the manufacturing space, half the investment in tools, half the engineering hours to develop a new product in half the time'

Schonberger (2007) notes that while this publication is commonly perceived to mark the beginning of the Lean movement, in reality Lean manufacturing was actually already well established in the US in the early 1980s, albeit under different names. 
Many authors have noted that there is a lack of a clear definition of Lean (Bhamu and Sangwan, 2014). Bayou and de Korvin (2008) reiterate Karlsson and Alhstrom's argument that the lack of a generally accepted definition contributes to the underdevelopment of the Lean concept (Karlsson and Alhstrom, 1996). Referring to the old fable of the blind men touching an elephant and imagining very different animals, the authors suggest that over time commentators on Lean have focused on a single, visible aspect of the process while missing the invisible highly interdependent links of Lean systems as a whole.

As well as being a poorly defined construct, interpretations of Lean have continued to evolve over time. Voss (1995) argues that the evolution of Lean illustrates the nature of operations management in the 1990s which consisted of three key elements: the core (which is both developing and providing a strong input to new areas and approaches); the interface (between operations management and other disciplines such as behavioural science, information management and strategy); and convergence (where new approaches such as Lean do not result from individual breakthroughs but from the convergence of many new and existing approaches).

Originally presented as a counter-intuitive alternative to traditional manufacturing (Krafcik, 1988; Shingo, 1989; Womack et al., 1990), Lean is now presented, by some at least, as a new paradigm for operations (Katayama and Bennet, 1996; Bartezzaghi, 1999; Bhasin and Burcher, 2006; Chaneski, 2009). It has expanded beyond its original applications on the shop floor of vehicle manufacturers to other functional areas within organisations, to other manufacturers and to non-manufacturing organisations (Hines et al., 2004; Beelaerts van Blokland et al., 2012; Moormann, 2014). Consequently, 'Lean' can be described as polymorphic; meaning different things to different people, at different moments in time. This notion is termed interpretive viability' in the literature (Ortman, 1995; Benders and Van Veen, 2001).

Lean has been criticised by many commentators for both lack of, and inadequacy of, theory (Anderson et al., 1989; Flynn et al., 1990; Swink and Way, 1995; Schmenner and Swink, 1998). Schmenner and Swink (1998) suggest that an operations management theory should exhibit certain characteristics: the operations management phenomenon for which explanation is sought should be clearly defined; the description of the phenomenon will centre on some observed regularities that have been derived logically or empirically; there should be one or more precise statement of these regularities, which are laws; and finally, the theory should indicate a mechanism or tell a story that explains why the laws work as they do and how, and in which ways the laws may be subject to limitations.

Although clearly positivist in their stance, the authors articulate such a theory, which they do not refer to as Lean, but which clearly describes and underpins Lean. It is a theory, which seeks to 
explain the phenomena of why one factory or service operation is more productive, as measured by inputs and outputs, than another. They refer to this as the Theory of Swift, Even Flow, which they define as: '....the more swift and even the flow of materials through a process, the more productive that process is' (Schmenner and Swink, 1998, p. 102).

Despite these issues Lean has evolved to be one of the best-known, yet fiercely debated, process improvement methodologies, which is still attracting much attention (e.g. Hasle et al., 2012; Krishna and Kodali, 2014). In this paper we are taking the IMVP Study and the subsequent publication of the book The Machine that Changed the World as a catalyst for a change in management thinking that has spanned 25 years and has endured much criticism. In the book Womack et al. predicted a wide-scale adoption of Lean that would spread through industry and, ultimately, change nations. In this paper we present an analysis of the writings on Lean from its inception in 1988 until 2013 to explore this prediction. Firstly by examining empirically through the literature if Lean has diffused and spread beyond the auto industry and, secondly, how this has been spread. By reviewing these archives we identify four core themes, which help to clarify the methods by which Lean has diffused and to help both practitioners and academics to unpack some of the confusion around this philosophy of improvement. Following this introduction first we provide an overview of the methodology employed including the development of a Lean Publications Database that demonstrates the diffusion of Lean. We then report on four key themes that were identified from the analysis of the publications. Finally, conclusions are drawn and we address the assertion by Womack et al:

'...the adoption of lean production, as it inevitably spreads beyond the auto industry, will change everything in almost every industry - choices for consumers, the nature of work, the fortune of companies, and, ultimately, the fate of nations' (Womack et al., 1990 cited by Brown, 2000 p. 256).

The research questions this paper addresses are firstly, 'what evidence in the literature supports the assertion that Lean has spread since the term entered the management lexicon in 1987 and was popularized by the publication of The Machine That Changed The World? Secondly, 'how has this occurred?' Finally, we conclude by considering whether The Machine and the popularisation of lean has actually changed industry and management thinking.

\section{Methodology}

The research was carried out by a systematic literature review guided by Hart (1998). "The systematic literature review is a method of locating, appraising and synthesising evidence" (Pettigrew et al., 2001). Four databases were selected for final use: ABI/INFORM Global 
(Proquest), Emerald library, EBSCO Business Source Premier and Google Scholar. In addition numerous management journals were studied to identify trends in industry specific sectors.

The data collection method is the development of a Lean publications database (LPD), which serves the primary purpose of providing quantitative evidence that Lean has diffused over time. The systematic review makes the reviewing process as structured, transparent, replicable and exhaustive as possible $(\mathrm{Wu}, 2006)$. In order to achieve these aims, a structured process was followed to design and implement the LPD (see figure 1).

\section{Take in Figure 1.}

A review of the literature on managerial fashions and fads advocates the use of longitudinal bibliometric data collection (Abrahamson and Fairchild, 1999; Carson et al., 1999). The LPD identifies patterns of publications on Lean over time and traces the nature of various publications as well as their frequency and occurrence. The LPD provides evidence of the shift in the Lean movement from its origins in manufacturing and into the service, public and third sectors more recently.

The LPD was based on the EndNote referencing database software which is generally used for storing and retrieving bibliographic references from online databases. To mitigate against the risk of accidental duplication of data, one database was selected. Business Source Premier (BSP) was found to provide full-text access to the most publications and was selected as the database from which publications information would be drawn. Like many online databases, BSP offers subject selection advice. It identified Lean Manufacturing as the best phrase to capture publications on Lean. However, the use of this phase alone would constrain the search to those publications that include both the terms Lean and manufacturing, potentially omitting other publications on Lean. On the other hand, searching with just the term Lean with, or without, a wildcard would cast the net too wide, capturing papers related to body mass etc. The potential phrases that could have been included are vast, however, the following terms (in Table 1) were chosen as representative, but by no means exhaustive, of a significant proportion of publications selected to represent a balance between breadth and focus. Publications between the years 1987 (the year prior to the one in which the term Lean was first coined) and 2013 were extracted from the BSP database and imported into the EndNote publications database.

\section{Take in Table 1}

The database is sufficiently representative to provide evidence of patterns of Lean discourse as a proxy for Lean diffusion over time and is a flexible data source that can be expanded in the future. 
To adjust for growth of articles during the period of 1987 to 2013 we employed an adjustment technique used by Abrahamson and Fairchild (1999) and Giroux (2006). The number of articles in any one year (from 1987 to 2013) is multiplied by an adjustment factor, which is the ratio between the total number of articles indexed on BSP in 1984 and the total number of articles indexed that year. This adjustment technique is "analogous to an approach employed by economists to transform nominal into real currency amounts, thereby factoring out the effect of inflation" (Abrahamson and Fairchild, 1999; p. 717).

\section{Findings}

To answer the first question 'has Lean diffused over time?' we look first at the growth and spread of Lean publications in the LPD.

The publications were reviewed for relevance to the study and, at the time of writing, the LPD included over 4130 publications on Lean, from both private and public sectors, such as automotive, aerospace, electronics, construction, financial services, education, healthcare and other public service government departments for example revenue and customs. The period 1987-1995 was dominated by automobile and automotive supply chain publications. From 1995 publications on aerospace and electronic industries emerged, followed by retail, construction, financial services and health. Since 2000 the body of literature in all sectors has increased substantially (Samuel, 2012) and spread to other public sector and public service organisations. In addition, more recent publications in innovation and new product/service development (Hines et al., 2006a; Morgan and Liker, 2006; Ward, 2007; Ries, 2011) and leadership, culture and human resource management (Mann, 2005; Koenigsaecker, 2009; Jekiel, 2011; Liker and Convis, 2012) have taken Lean beyond the traditional fields of operations and process improvement into more enterprise-wide areas (Moyano-Fuentes, and Sacristán-Díaz, 2012; Moyano-Fuentes et al., 2012).

Figure 2 shows the unadjusted counts and Figure 3 shows the counts, adjusted for growth in the total number of academic articles that year, for the period of 1987 to 2013. Both figures illustrate the steady rise in publications since the term entered the management lexicon in 1988. Figure 2 also illustrates the early interest in Lean among the academic community. Interest in Lean was dominated by academia between the years 1993 and 1998. Since that time, Lean has featured in all types of publication. Previous research on management fashions (Abrahamson and Fairchild, 1999) has sought to explain patterns of management interventions discourse by the interest in different types of publication. For example, Abrahamson and Fairchild (1999) explain the gradual decline of discourse in Quality Circles by the persistent interest from the semi-academic and academic press long after the business press lost interest. The findings presented here, however, 
do not show similar patterns in Lean discourse. The broader implication of this finding may be that Lean fails to exhibit similar patterns to other management improvement interventions regarded as transitory management fashions. This may be an area suitable for further research.

\section{Take in Figures $2 \& 3$}

With over two decades of Lean history, it is possible to identify patterns of Lean discourse over time. Hardy (2010) defines discourse as 'an inter-related body of texts (including practices of their production, distribution and consumption), that bring so-called "reality" into being' (Hardy, 2010).

The authors identify four main themes of discourse within the extant Lean literature that seek to explain how Lean has diffused through the literature. They are:

1. Lean as a generic representation of Toyota Production Systems (TPS)

2. Lean as a process improvement methodology for an organisation to use and follow

3. Lean as an ideological movement that has emerged and progressed over time

4. Lean as a polarized body of academic literature that has developed over time

Each of these themes is addressed in turn to understand the diffusion of Lean and the supporting mechanisms that were responsible for a global shift in management thinking.

\section{Lean as a Generic Representation of Toyota Production System (TPS)}

'Over the course of the last three decades, the basic ideas behind the TPS... have been published under a wide variety of labels, with 'lean' arguably being the most prominent' (Benders and Slomp, 2009, p. 5242).

Lean emerged at a time of great interest in Japanese production and management methods generally; and particularly Toyota and the Toyota Production System (TPS). Toyota's business success and world-leading product quality is an established fact (Schonberger, 1996; Standard and Davis, 1999, 2000; Liker, 2004; New, 2007). Rother (2010) recently summarised Toyota's success into four key statistics: Toyota has shown sales growth for over 40 years (at the same time other car maker's sales reached a plateau or declined); Toyota's profit exceeds that of other car makers; Toyota's market capitalisation has for many years exceeded that of other car makers; and, in sales ranking Toyota has become the world leading car maker. This success is often attributed to the production system that Toyota developed during the 50s and $60 \mathrm{~s}$ as a result of intense post war competition. The TPS remained largely unknown in the west until interest was stimulated by the second oil crisis (Holweg, 2007). This interest led to the publication of two English language articles in 1977; one by Sugimori et al. in the International Journal of Production Research and the other by Ashburn in the American Machinist (Schonberger, 2007). The TPS is characterised by a systematic approach to the organisation of production that emphasises the 
elimination of all forms of waste to ensure that value to the customer flows swiftly and smoothly (Ohno, 1978, 1988; Monden, 1983). However, over time TPS has been discovered to be a complex, multi-faceted element of Toyota's broader management system and culture (Spear and Bowen, 1999; Liker, 2004; Hines et al., 2004, 2011; Holweg, 2007; Seddon, 2005; Spear, 2009; Rother, 2010). As Vasilash (cited in Bicheno and Holweg, 2009, p. 1) puts it: 'The TPS is an interlocking set of three underlying elements: philosophical underpinnings, managerial culture, and technical tools - a triangle, where human development is at the core'.

Paralleling the nebulous nature of the Lean concept, the TPS itself has been described variously as a method, a process, a strategy, a goal, a belief or state of mind and a philosophy (Vokurka and Davis, 1996). Furthermore, TPS is not a static entity. It has evolved over time, presenting further difficulties in defining and understanding it (Spear and Bowen, 1999; Benders and Morita, 2004; Lee and Jo, 2007; Spear, 2009).

Detailed chronologies of the events and publications that led up to the emergence of the TPS and subsequent Lean phenomena have been well documented in Holweg (2007), Shah and Ward (2007), Schonberger (2007), and Bicheno and Holweg (2009). Table 2 offers a synthesis of these works and includes those events and publications regarded by the authors to be the most important.

\section{Take in Table 2}

Most authors therefore locate the origins of Lean as the culmination of research conducted during the 1980s at MIT within the IMVP (e.g. Hines et al., 2004; Papadopoulos and Ozbayrak, 2005; Bhasin and Burcher, 2006; Rich et al., 2006; Holweg, 2007). The high-profile IMVP involved a global network of academics, from which many established or enhanced their career and produced notable Lean publications e.g. Nishiguchi (1990), Lamming (1992), Nobeoka (1988), Fujimoto, (1989) and Graves (1991).

Other authors position the emergence of Lean within a 'Japanisation' debate (Turnbull, 1986) that had been ongoing amongst a group of UK academics (Ackroyd et al. 1988; Oliver and Wilkinson, 1988; Elgar and Smith, 1994; Stewart, 1996). Many of these were located in the human resources field of management (Schonberger, 2007). During the 80s and 90s the Japanese economy was expanding rapidly and Japanese companies were attracted into the UK and USA by the policies of the Regan \& Thatcher governments. The clustering of Japanese 'transplants' (meaning Japanesemanaged plants, Cusumano and Takeishi, 1991) incited an interest in the academic community, fuelling a fierce debate, leading to the conclusion Lean emerged from, and caused debate within, the 'Japanisation School' of late 80s and early 90s. 
Other authors, such as Dinero (2005), Huntzinger $(2002,2006)$ and Graupp and Wrona (2006) locate the origins on Lean with the 'Training Within Industry' (TWI) programme that was developed by the US government and industry during World War II.

Although the precise origins and antecedents of Lean are disputed, The Machine That Changed the World (or The Machine) is generally agreed as the publication that established the Lean phenomenon (Oliver et al., 1994; Karlsson and Alhstrom, 1996; Katayama and Bennett, 1996; Benders and Bijsterveld 2000; Bhasin and Burcher, 2006; Shah and Ward, 2007).

The findings of the IMVP study are positioned within an historical context which presents the automotive industry as being in transition from mass production, as exemplified by Ford's Production System (FPS), to the newly emerged Lean production, as exemplified by Toyota's Production System (TPS). The book, The Machine, is divided into sections that explain the origins, constituent elements and diffusion of Lean Production. Lean Production, then, is presented as the new dominant paradigm that is displacing, and will continue to displace, mass production in search for methods to compress time and increase flow.

The Machine has three noteworthy features. First, it represents TPS under the more generic and less culturally specific label of Lean Production. Oliver and Hunter, in Delbridge and Lowe, (1998, p.81) pinpointed the relevance of this relabeling:

'Lean Production is significant because it represents an attempt to take Japanese methods out of their Japanese context, and elevate them to the status of universal principles that, properly applied, can produce elsewhere in the world the same outcomes as occur in Japan'

The de-contextualisation that the above authors refer to was welcomed as an important demystification for many commentators; however, others (Williams et al., 1992; Coffey, 2006) regarded it as a gross misrepresentation.

Second, The Machine presents empirical evidence in support of the superiority of Lean Production/TPS over traditional manufacturing methods based on outmoded mass production logic, Ford Production System (FPS) or 'Fordism'. The empirical evidence includes an initial pilot study of two plants representing classic mass versus classic Lean production. The Lean plant is found to be almost twice as productive and able to produce at three times the quality level of the classic mass production plant (Womack et al., 1990, p. 81). The pilot study was extended to include the GM-Toyota NUMMI joint venture in order to test whether a mass production plant can transform into a Lean production plant. NUMMI was found to match the classic Lean production plant in terms of quality and almost match in terms of productivity (ibid, p. 83). In the main study, information is obtained from more than 90 car assemblers around the globe. The authors 
estimated that their sample represented about half the world's global car manufacturing capacity (ibid, p. 75). The findings show that all Lean plants, defined as those able to achieve both high productivity and high quality levels, are Japanese, although not all Japanese plants are Lean (ibid, p. 83). The authors interpret the findings as evidence that Lean production can be reproduced anywhere in the world (ibid, p.88).

Third, the essential elements of Lean Production are identified as differences in: organising and running the factory, designing and product development, coordinating the supply system and managing customer relations. However, the complexity and interaction of these elements are reduced to a simple axiom of Lean Production's superiority and an imperative is established asserting that Lean Production should be universally adopted: 'Our conclusion is simple: Lean production is a superior way for humans to make things.........It follows that the whole world should adopt lean production, and as quickly as possible' (Womack et al., 1990, p. 225).

It is clear Lean has evolved over time from a generic description of TPS to a particular type of organizational and management intervention focused on best practice and process improvement methodologies.

\section{Lean as a process improvement methodology for an organisation to follow and use}

Lean is one of the best-known process improvement methodologies (Bhuiyan and Baghel, 2005). It emerged during a proliferation of such methodologies in business and management literature (Pascale, 1990; Ettorre, 1997; Appleyard, 2009). Pascale (1990) counted more than thirty such management interventions between 1950 and 1988 and many appeared in the form of bestselling management books (Cummings, 1983). The Machine and subsequent publications by its authors are typical examples of these best selling management books that seek to articulate good or best practice in management and business.

The other interventions that emerged during the 1990s generally build on the basic concepts of quality or process improvement through productive restructuring (Goldstein, 1997). They include Total Quality Management (TQM), Six Sigma, Business Process Reengineering (BPR), Just In Time (JIT), Theory of Constraints (TOC), World Class Manufacturing, Kaizen and Business Excellence, to name a few. They all have common aims (minimising waste and resources, reducing lead-time, and increasing flow to improve customer satisfaction and financial results) and common origins (the quality evolution in Japan after the Second World War). Furthermore, they all represent ways of achieving more swift and even flow (Schmenner and Swink, 1998). Most of these other process improvement methodologies are both complementary and competitive to Lean. They are complementary in the sense they may be implemented alongside Lean and are 
competitive in the sense they compete with Lean in the market for process improvement methodologies.

The Lean process improvement methodology has been examined from many perspectives and expanded in different ways. Some authors have examined the application of the Lean process improvement methodology in the wider supply chain (Lamming, 1993; 1996; Bicheno, 1994; Hines, 1994; Levy, 1997; Hines and Rich, 1997; Jones et al., 1997; Christopher and Towill, 2000; Hines et al., 2000; Moyano-Fuentes et al., 2012). More recently, a group of authors have focused on the inability of conventional accounting to compliment and support the Lean process improvement methodology (Maskell and Baggaley, 2004; Darlington, 2010). Darlington et al., (2008) argue that Lean Accounting has become the foremost topic of discussion amongst Lean practitioners over the last two years. As a consequence of the dislocation between conventional accounting and Lean several alternative accounting approaches have been developed (Monden, 1989; Monden and Hamada, 1992; Maskell and Baggaley, 2004; Hines, 2006; Hines et al., 2006b; Darlington, 2011).

\section{Lean as an ideological movement that has emerged and progressed over time}

The Machine spawned a movement amongst industrial practitioners to follow the imperative set out in the book. The Lean revolution is clearly underway in US manufacturing companies; Rio (2005) claims that over $50 \%$ of manufacturing companies in the discrete industries are using Lean as their primary improvement methodology. More recently, a census of US manufacturing companies concluded that nearly $70 \%$ of all plants have adopted Lean (Blanchard, 2007).

A movement is defined as a series of actions and events taking place over a period of time and working to foster a principle or policy (Collins, 1999). Whilst previous sections suggested there are a number of antecedents to Lean, the Lean movement is generally traced back to the publication of The Machine (Delbridge and Oliver, 1991; Oliver et al., 1994; Karlsson and Alhstrom, 1996; Katayama and Bennett, 1996; Panizzolo, 1998; Dyer and Nobeoka, 2000; Benders and Bijsterveld 2000; Bhasin and Burcher, 2006; Shah and Ward, 2003, 2007). The Lean movement therefore spans two decades and continues to provide the rationale for much activity in a great many organisations.

Commentators generally agree that the Lean movement has had considerable impact over the last two decades. Lean is described as:

'a dominant strategy for organising production systems'

(Karlson and Ahlstrom, 1996 p.2 5); 
'arguably the paradigm for operations and its influence can be found in a wide range of manufacturing and service strategies'

(Lewis, 2000, p. 959);

'an integral part of the manufacturing landscape'

(Shah and Ward, 2007, p. 785);

As further evidence of the spread Lean as an ideological movement, the authors of The Machine and Lean Thinking, have set up organisations with the specific aim of promoting Lean: Womack in the US; Jones in the UK and the rest of Europe. These have affiliated organisations in seven European countries (including the UK) and five non-European countries (see www.lean.org). Womack states that the Lean movement is widespread and far-reaching:

'I am delighted with the spread of lean thinking far beyond the factory and far beyond the high-wage economies to every corner of the world and to every value-creating activity. My greatest concern is that we bring the best methods to bear and create the maximum amount of knowledge exchange across the global Lean Community so these initiatives will all succeed. Life will be better for all of us if they do' (Jim Womack, The Dramatic Spread of Lean Thinking, LEI, 11 th April 2005).

Papadopoulos and Ozbayrak (2005) argue that Lean has undergone and is still undergoing a process of continuous evolution and much of the literature on Lean relies on an antiquated version of Lean that has failed to keep up with this evolution. Similarly, Hines et al., (2004) propose that the Lean movement has evolved over time. They identify four distinct phases of the movement and the focus, literature themes, contributors and active sectors of each phase.

The authors suggest that the Lean movement has evolved and adapted over time in order to address inherent weaknesses in the previous phase. The awareness period, prior to the publication of The Machine, saw the movement limited to some emulation of certain structural elements of TPS, such as Just-in-Time (JIT). However, the publication of The Machine saw a widening of the focus of Lean movement from the shop floor to the simultaneous pursuit of quality, cost and delivery. More recently, the focus of the Lean movement has shifted to value appropriation rather than cost (waste) reduction. As such a story is emerging to explain how, and why, the application of Lean thinking to different scenarios works in different ways and why often counter-intuitive approaches offer enhanced performance.

\section{Lean as a polarized body of academic literature that has developed over time}

The academic literature on Lean is located primarily in the operations and organisational behaviour fields of inquiry within broader business and management literature. Harrison and Storey (1996) propose this creates both tensions and limitations with the literature. While the 
operations management literature tends to ignore social and organisational dimensions; the organisational behaviour literature fails to fully engage with the technical aspects of Lean.

However, it is not the bold claims so much as the standard scientific form of the evidence presented in The Machine that was the key ingredient of the success of the publication. Almost two decades later, Holweg (2007) presents an historical account of the research activity that led to the formation and dissemination of Lean, which he regards as one of the most influential manufacturing paradigms.

While Holweg (2007) successfully captures much of the story and a complex web of activity leading up to the IMVP study, as a self-proclaimed supporter of Lean, his work lacks critical evaluation. For example, the point made by the authors regarding the intended audience for the publication is contradicted in the text itself, where they state, 'Our story is not just for an industry audience but for everyone - government officials, labour leaders, industry executive, and general readers - in every country with an interest in how society goes about making things' (Womack et al., 1990, p. 8).

The broader issue here concerns the blurring of the boundaries between practitioner and academic communities, and the resultant effects. This issue is a recurrent theme of this study. Furthermore, the empirical evidence in The Machine has been challenged for both methodological robustness (Williams et al., 1994) and for interpretive validity (Coffey, 2006, 2007; Coffey and Thornley, 2006; 2007). Yet there is no mention of these challenges. Finally, the universal application claims within The Machine are also ignored in the self-assessment in spite of their having stimulated widespread debate and criticism (Cusumano, 1994; Katayama and Bennett, 1996; Miyai, 1996; James-Moore and Gibbons, 1997; Jina et al., 1997; Cooney, 2002).

Within this polemic literature it is possible to identify five main schools of Lean critics:

1. Those critics of the style and narrative devices of The Machine. (Delbridge, 1995; New, 2007; Williams et al.,1992, 1994)

2. Those critical of the empirical evidence contained in The Machine (Williams et al., 1994; Katayama and Bennett, 1996; Coffey, 2006; Coffey and Thornley, 2006).

3. Those critical of the effects of Lean on the workforce (Wilkinson and Oliver, 1989; Sewell and Wilkinson, 1992; Delbridge et al., 1992)

4. Those critical of the transfer and universal application claims of Lean (Cooney, 2002; James-Moore and Gibbons, 1997, Seddon, 2005).

5. Those critical of he financial benefits of Lean (Oliver and Hunter, 1998) 
New (2007, p.3547) is more critical of The Machine. He highlights the role of politics in the publication:

'We should note that there is always politics at work when people explain these ideas, inevitably affected by the interests and agendas of whoever is doing the explaining. The authors of The Machine now speak candidly that they coined 'lean' as an acceptable way of describing TPS without offending the sponsors of the IMVP research.'

In 1996, Womack and Jones produced a follow-up text entitled Lean Thinking in which they identify the core principles of Lean Production. The five Lean principles presented in Lean Thinking through case studies represent a roadmap for organisations attempting to implement Lean or emulate Toyota Production System (TPS) in some way; consequently, this publication had less impact on the academic community than the practitioner community. Spear and Bowen (1999) also provide a set of principles to characterise TPS: standardisation of work; seamless workflows; direct links between suppliers and customers; and, continuous improvement based on scientific methods. Shah et al. (2008) argue that practices are the physical manifestation of Lean principles, which explains why much of the empirical data are case studies.

Brown (2000) pointed to the lack of strategic resonance in many early Lean implementations that limited the spread and wholesale adoption of Lean, which was asserted boldly by Womack et al. in The Machine in 1990;

'...the adoption of lean production, as it inevitable spreads beyond the auto industry, will change everything in almost every industry - choices for consumers, the nature of work, the fortune of companies, and, ultimately, the fate of nations' (Womack et al., 1990 cited by Brown, 2000 p. 256).

\section{Conclusions}

From the evidence in the literature Lean has clearly spread well beyond the traditional Japanese automotive manufacturing roots and has evolved over time from a generic description of TPS to a particular type of organisational and management intervention focused on best practice and process improvement methodologies adopted, and adapted, by public and private sector organisations around the world. From a systematic review of the extant literature published on Lean from 1988 to 2013, we have identified four key themes that have emerged: Lean as a representation of TPS which highlighted the origins and antecedents of Lean; Lean as a process improvement methodology which highlighted the need to compare Lean with other process improvement methodologies; Lean as a movement which highlighted the characteristics of Lean's evolution over time; and Lean as academic body of literature which highlighted the diversity of perspective and opinion that Lean has inspired. These themes relate to observed regularities, 
which contributed to the emergence and establishment of Lean as a management improvement paradigm that diffused from automobile manufacturing to all industries in all sectors around the world. Duguay et al., (1997) noted this paradigm shift from mass production and argued that the era of mass production as the dominant production paradigm ended in the 1980s and was succeeded by a new, customer-focussed paradigm. They further argue that the proliferation of improvement methodologies in the late 1990s could be associated with paradigmatic chaos (Kuhn, 1962 cited in Duguay et al., 1997) from which the new paradigm emerged. They contend we have now entered the era (21st century) where Lean and flexible producers dominate.

This paper demonstrates despite the many criticisms of Lean, and the lack of formal definition, Lean has emerged as a dominant global operations paradigm focussed on reducing variability and compressing time in order to improve flow. To criticise it for lack of theoretical underpinning is misguided since this can be identified through the theory of swift, even flow (Schmenner and Swink, 1998). In a later publication Schmenner (2012) made clear the link between Lean and the theory of Swift, Even Flow and it is our contention, then, that this paper contributes to this and theory development in operations management.

Our critical analysis of the literature offers both academics and practitioners alike with a greater understanding of Lean and its evolution over time. It provides clarity around the meaning of Lean and includes both advocates and critics of Lean. As Lean has grown from its origins of manufacturing to service based industries there is a need to continually review writings on Lean to ensure that the learning is disseminated to the community of improvers.

We believe that Lean, from its origins in 1988 and the popularization of the concept by the publication of The Machine, has changed the way industries behave and that our paper has provided a wealth of evidence in support of this belief. Specifically, we summarise the impact of The Machine, as: making the TPS accessible to a wider audience; widening the focus from the shop floor to the key measures of quality, cost and delivery; creating a movement from cost reduction to value appropriation; and stimulating discussion around alternative business and accounting approaches.

Would Lean have had the impact it had without the publication of The Machine? This is different question. Undoubtedly there was significant interest in Japanese Just-in-Time (JIT) manufacturing techniques well before the book was written; it was this interest and the performance improvements that had prompted the MIT research, and the term 'Lean' had emerged from the paper by John Krafcik (1988). However, we believe that, although, managers would have continued to pursue 'best practice' and operational improvements, and they may well have adopted many of the tools and techniques that we have come to know as Lean tools, this 
would have been through less focussed and, possibly, would not have achieved the same operational improvements. What The Machine did was to focus the operational improvements around the term 'Lean' and made this accessible to managers around the world. This created a movement, supported by governments and criticised by other academics that, together with a structure, or framework, in the form of the 5 Lean Principles from the subsequent publication of Lean Thinking took Lean to a new level that could, justifiably, claim to be a paradigm shift in operations management.

In a recent video interview (Gemba Academy, 2014) Womack, Jones and Shook were posed the question "If they had it all to do again, would they still call it 'Lean'”? Womack explained that they had to have a name, but at that time, mid-1980s, people wanted to apply a Japanese word or name it after a person or company. As they wanted to make it more accessible they wanted something different. Krafcik, in a workshop, suggested that they name it for what it does, rather than try to explain what it is. They listed all the things it did: less time; less effort; fewer resources etc. so the name 'Lean' was proposed. Womack seconded this and Jones agreed it, so the name 'Lean' was born. Womack said, on reflection, what they were focussing on was "MORE (or better) value with less", but what was heard was "more for LESS" and many people interpreted this as less people, less plants and the expression "Lean and Mean" was used. Jones said the word "Lean", like other words in the English language, did not translate well and it was a struggle to explain it in other languages. As a result the term 'Lean' was introduced into the business language in German, French, Portuguese and Japanese, so Lean now has an identity, a meaning and a reference point (the Toyota Reference Model) around the world.

This paper should be of interest to academics in the field of operations management, specifically those seeking to understand the popularising of The Machine and Lean within the business community. It is also likely to be of interest to policy makers, as considerable amounts of public money have been spent, and continue to be spent, on promoting Lean. Taxpayers and policymakers are likely to be interested in whether that expenditure is justifiable.

Twenty-five years on and Lean has touched many aspects of our everyday lives beyond how companies structure, operate and organise themselves. Lean has influenced the way we operate our education and healthcare systems. It is clear Lean has come a long way from its shop floor origins in the best car-making companies. It continues to evolve today and to infiltrate our strategic and operational management thinking into the twenty-first century. Future research has two roles to play. First, continue to evaluate and report the evolution of Lean. Second, provide a better understanding of the cross-fertilisation of improvement methodologies, such as Lean and Six Sigma and the innovation this brings to organisation performance and management thinking. 


\section{References}

Abrahamson, E. and Fairchild, G. (1999), "Management Fashion: Lifecycles, Triggers and Collective Learning Processes", Administrative Science Quarterly, Vol. 44, pp. 708-740.

Ackroyd, S, Burrell, A. Hughes, M. and Whitaker, A. (1988), "The Japanisation of British Industry?", Industrial Relations Journal, Vol. 19 No. 1, pp. 11-23.

Anderson, J. Cleveland, G. and Schroeder, R. (1989), “Operations Strategy: A Literature Review”, Journal of Operations Management, Vol. 8 No. 2, pp. 133-158.

Anderson, (1992), The Lean Enterprise Report. Anderson Consulting, London.

Anderson, (1994), Worldwide Manufacturing Competitiveness Study: The Second Lean Enterprise Report, Anderson Consulting, London.

Appleyard, B. (2009), "Books that Helped to Change the World", The Sunday Times, 19th July.

Bartezzaghi, E. (1999), "The Evolution of Production Models: Is a New Paradigm Emerging?," International Journal of Operations and Production Management, Vol. 19 No. 2, pp. 229-250.

Bayou, M.E. and Korvin, A.D. (2008), "Measuring the Leanness of Manufacturing Systems: A Case Study of Ford Motor Company and General Motors", Journal of Engineering \& Technology Management, Vol. 25 No. 4, pp. 287-304.

Beelaerts van Blokland, W.W.A. Fiksinski, M.A. Amoa, S.O.B. Santema, S.C. van Silfhout, G.J. and Maaskant, L. (2012), "Measuring value-leverage in aerospace supply chains", International Journal of Operations \& Production Management, Vol. 32 No. 8, pp.982-1007.

Benders, J. and Bijsterveld, M.V. (2000), "Lean on Lean: The Reception of Management Fashion in Germany", New Technology, Work and Employment, Vol. 15 No. 1, pp. 50-64.

Benders, J. and Morita, M. (2004), "Changes in Toyota Motors Operations Management", International Journal of Production Research, Vol. 42 No. 3, pp. 433-444.

Benders, J. and Slomp, J. (2009), "Struggling with Solutions A Case Study of Using Organisation Concepts”, International Journal of Production Research, Vol. 47 No. 18, pp. 5237-5243.

Benders, J. and Van Veen, K. (2001), "What's in a Fashion? Interpretive Viability and Management Fashions”, Organisation, Vol. 8 No. 1, pp. 33-53.

Bhamu, J. and Sangwan, K.S. (2014),"Lean manufacturing: literature review and research issues", International Journal of Operations \& Production Management, Vol. 34 No. 7, pp. 876-940.

Bhasin, S. and Burcher, P. (2006), "Lean Viewed as a Philosophy", Journal of Manufacturing Technology Management, Vol. 17 No. 1, pp. 56-72.

Bhuiyan, N. and Baghel, A. (2005), "An Overview of Continuous Improvement: from the Past to the Present", Management Decision, Vol. 43 No. 5/6, pp. 761-771.

Bicheno, J. (1994), Cause and Effect JIT: The Essentials of Lean Manufacturing, Picsie Books, Buckingham. 
Bicheno, J. and Holweg, M. (2009), The Lean Toolbox: The Essential Guide to Lean Transformation. Picsie Books, Buckingham.

Blanchard, D. (2007), “Lean Green and Low Cost”, Industry Week/IW, Vol. 256 No. 10, pp. 37-39.

Brown, S. (2000), Manufacturing the Future: Strategic Resonance for Enlightened Manufacturing, Financial Times Books, London.

Carson, P. Lanier, P. Carson, K. and Birkenmeier, B. (1999), "A Historical Perspective on Fad Adoption and Abandonment”, Journal of Management History, Vol. 5 No. 6, pp. 320-333.

Chaneski, W. (2009), "Lean Concepts Really Do Apply in All Industries", Modern Machine Shop, Vol. 81 No. 11, pp. 34-36.

Christopher, M. and Towill, D. (2000), "Supply Chain Migration from Lean and Functional to Agile and Customised", Supply Chain Management: An International Journal, Vol. 5 No. 4, pp. 206-213.

Coffey, D. (2006), The Myth of Japanese Efficiency: The World Car Industry in a Globalizing Age, Edward Elgar Publishing Limited, Cheltenham.

Coffey, D. (2007), “Lean Beginnings”, Manufacturing, Vol. June/July, pp. 18-19.

Coffey, D. and Thornley, C. (2006), "Automation, Motivation and Lean Production Reconsidered", Assembly Automation, Vol. 26 No. 2, pp. 98-103.

Coffey, D. and Thornley, C. (2007), "Can Japan Compete? Reconsidered”, Chapter 10 in Bailey, D. Coffey, D. and Tomlinson, P. (Eds.), Crisis or Recovery in Japan: State and Industrial Economy, Edward Elgar Publishing, Cheltenham.

Collins (1999), Family English Dictionary, Harper Collins, Glasgow.

Cooney, R. (2002), “Is 'Lean' a Universal Production System? Batch Production in the Automotive Industry", International Journal of Operations and Production Management, Vol. 22 No. 10, pp. 1130-1147.

Cummings, L. (1983), “The Logics of Management", Academy of Management Review, Vol. 8 No. 4, pp. 532-538.

Cusumano, M. (1994), “The Limits of Lean”, Sloan Management Review, Vol. 35 No. 4, pp. 27-32.

Cusumano, M. and Takeishi, A. (1991), "Supplier Relations and Management: A Survey of Japanese, Japanese-Transplant, and US Auto Plants", Strategic Management Journal, Vol. 12 No. 8, pp. 563-588.

Darlington, J. (2010), “Accounting for Lean”, Lean Management Journal, Vol. 7.

Darlington, J. Found, P. and Jones, D. (2011), "Finding the Financial Impact", Lean Management Journal, Vol. 8 Jan/Feb, pp. 30-38.

Darlington, J. Francis, M. and Found, P. (2008), "Flow Accounting Effective Performance Assessment for the Lean Enterprise" in Proceedings of 13th International Symposium on Logistics, Bangkok, Thailand, 2008, pp. 53-61. 
Delbridge, R. (1995), British Factory: Japanese Transplant; an Ethnographic Study of Workplace Relations, PhD Thesis, Cardiff University, Cardiff.

Delbridge, R. and Lowe, J. (1998), British Manufacturing in Perspective. Routledge, Oxford.

Delbridge, R. and Oliver, N. (1991), "Narrowing the Gap? Stock turns in the Japanese and Western Car Industries”, International Journal of Production Research, Vol. 29 No. 10, pp. 2083-2095.

Delbridge, R. Turnbull, P. and Wilkinson, B. (1992), "Pulling Back the Frontiers: Management Control and Work Intensification Under JIT/TQM Factory Regimes”, New Technology, Work and Employment, Vol. 7 No. 2, pp. 83-148.

Dinero, D. (2005), Training Within Industry: The Foundation of Lean, Productivity Press, NY.

Duguay, C.R. Landry, S. and Pasin, F. (1997), "From mass production to flexible/agile production", International Journal of Operations and Production Management, Vol. 17 No. 12, pp. 1183-1195

Dyer, J. and Nobeoka, K. (2000), "Creating and Managing a High Performance Knowledge-Sharing Network: The Toyota Case", Strategic Management Journal, Vol. 21 No 3, pp. 345-367.

Elgar, T. and Smith, C. (1994), Global Japanization? The Transnational Transformation of the Labour Process, Routledge, London.

Ettorre, B. (1997), “What's The Next Business Buzzword?", Management Review, Vol. 86 No 8, pp. 33-35.

Flynn, B. and Sakkakibara, S. Schroeder, R. Bates, K. and Flynn, J. (1990), "Empirical Research Methods in Operations Management", Journal of Operations Management, Vol. 9 No. 2, pp. 250284.

Fujimoto, T. (1989), Organisations for Effective Product Development - the Case of the Global Automobile Industry. PhD thesis, Harvard Business School, Boston.

Gemba Academy, (2014), "Reflections on 25 Years of Lean", available at http://www.gembaacademy.com/promo/25-years-of-lean.html (accessed 21st August 2014).

Giroux, H. (2006), "It was such a handy term: Management Fashions and Pragmatic Ambiguity", Journal of Management Studies, Vol. 43 No. 6, pp. 1227-1260.

Goldstein, D. (1997), "Clashing Paradigms? Total Quality, Financial Restructuring and the Theories of the Firm", Industrial and Corporate Change, Vol. 6 No. 3, pp. 665-700.

Graupp, P. and Wrona, R.J. (2006), The TWI Workbook: Essential Skills of Supervisors, Productivity Press, New York, NY.

Graves, A. (1991), International Competitiveness and Technology Development in the World Automotive Industry, $\mathrm{PhD}$ thesis, University of Sussex, Brighton.

Hardy C. (2010), Doing Discourse Analysis, University of Melbourne, Australia. 
Harrison, A. and Storey, J. (1996), "New Wave Manufacturing Strategies: Operational, Organisational and Human Dimensions", International Journal of Operations \& Production Management Vol. 16 No. 2, pp. 63-76.

Hart, C. (1998), Doing a Literature Review. Sage Publications, London.

Hasle, P. Bojesen, A. Jensen, P.L. and Bramming, P. (2012),"Lean and the working environment: a review of the literature", International Journal of Operations \& Production Management, Vol. 32 No. 7, pp. 829-849.

Hines, P. (1994), Creating World Class Suppliers, Pitman Publishers, London.

Hines, P. (2006), "Contingent Approaches to Quality Based Pricing in the Agrifood Industry", The International Journal of Logistics: Research and Applications, Vol. 9 No. 3, pp. 223-236.

Hines, P. Found, P. Griffiths, G. and Harrison, R. (2011), Staying Lean: Thriving, Not Just Surviving, Second ed. Productivity Press, NY.

Hines, P. Francis, M. and Found, P. (2006a), "Towards lean product lifecycle management: a framework for new product development", Journal of Manufacturing Technology Management Vol. 17 No. 7, pp. 866-888.

Hines, P. Francis, M. and Bailey, K. (2006b), "Quality Based Pricing: A Catalyst for Collaboration and Sustainable Change in the Agrifood Industry", The International Journal of Logistics Management, Vol. 17 No. 2, pp. 240-259.

Hines, P. Holweg, M. and Rich, N. (2004), "From Strategic Toolkit to Strategic Value Creation: A Review of the Evolution of Contemporary Lean Thinking", International Journal of Operations and Production Management, Vol. 24 No. 10, pp. 994-1011.

Hines, P. Lamming, R. Jones, D. Cousins, P. and Rich, N. (2000), Value Stream Management: Strategy and Excellence in the Supply Chain. FT Prentice Hall, London.

Hines, P. and Rich, N. (1997), "The Seven Value Stream Mapping Tools", International Journal of Operations \& Production Management, Vol. 17 No. 1, pp. 46-64.

Holweg, M. (2007), "The Genealogy of Lean Production", Journal of Operations Management, Vol. 25 No. 2, pp. 420-437.

Huntzinger, J. (2002), "The Roots of Lean - Training Within Industry: The Origin of Japanese Management and Kaizen", Target, Vol. 18 No. 4, pp. 6-9.

Huntzinger, J. (2006), "Why Standard Work is not Standard: Training Within Industry Provides an Answer", Target, Vol. 22 No. 4, pp. 7-13.

James-Moore, S. and Gibbons, A. (1997), "Is Lean Manufacture Universally Relevant", International Journal of Operations and Production Management Vol. 17 No. 9, pp. 899-911.

Jekiel, C.M. (2011), Lean Human Resources: Redesigning HR Processes for a Culture of Continuous Improvement, CRC Productivity Press, New York. 
Jina, J. Bhattacharya, A. and Walton, A. (1997), "Applying Lean Principles for High Product Variety and Low Volumes: Some Issues and Propositions”, Logistics Information Management, Vol. 10 No. 1, pp. 5-13.

Jones, D. Hines, P. and Rich, N. (1997), "Lean Logistics", Internal Journal of Physical Distribution and Logistics Management, Vol. 27 No. 3/4, pp. 153-157.

Karlsson, C. and Ahlstrom, P. (1996), "Assessing Changes Towards Lean Production Management", International Journal of Operations and Production Management, Vol. 16 No. 2, pp. 24-41.

Katayama, H. and Bennett, D. (1996), "Lean Production in a Changing Competitive World: A Japanese Perspective", International Journal of Operations and Production Management, Vol. 16 No. 2, pp. 8-23.

Koenigsaecker, G. (2009), Leading the Lean Enterprise Transformation. CRC Productivity Press, New York.

Krafcik, J. (1988), "The Triumph of the Lean Production System”, Sloan Management Review, Vol. 30 No. 1, pp. 41-52.

Krishna, N.V. and Kodali, J.R. (2014),"A literature review of empirical research methodology in lean manufacturing", International Journal of Operations \& Production Management, Vol. 34 No. 8, pp. 1080-1122.

Lamming, R. (1992), Supplier Strategies in the Automotive Components Industry: Development Towards Lean Production. PhD thesis, University of Sussex, Brighton.

Lamming, R. (1993), Beyond Partnership: Strategies for Innovation and Lean Supply. Prentice Hall, Hemel Hempstead, UK.

Lamming, R. (1996), "Squaring Lean Supply with Supply Chain Management", International Journal of Operations \& Production Management, Vol. 16 No. 2, pp. 183-196.

Lee, B. and Jo, H. (2007), "The Mutation of the Toyota Production System: Adapting the TPS at Hyundai Motor Company", International Journal of Production Research, Vol. 45 No. 15/16, pp. 3665-3679.

Levy, D. (1997), "Lean Production in an International Supply Chain", Sloan Management Review, Vol. Winter, pp. 94-102.

Lewis, M. (2000), "Lean Production and Sustainable Competitive Advantage", International Journal of Operations and Production Management, Vol. 20 No. 8, pp. 959-978.

Liker, J. (2004), The Toyota Way: 14 Management Principles from the World's Greatest Manufacturer, McGraw-Hill, NY.

Liker, J. and Convis, G.L. (2012), The Toyota Way to Lean Leadership: Achieving and sustaining excellence through leadership development, McGraw-Hill, NY. 
Mann, D. (2005), Creating a Lean Culture: Tools to Sustain Lean Conversions, Productivity Press, New York.

Maskell, B. and Baggaley, B. (2004), Practical Lean Accounting: A Proven System for Measuring and Managing a Lean Enterprise, Productivity Press, NY.

Miyai, J. (1996), “The Redesign of Japanese Management Systems and Practices”, APO Productivity Journal, Vol. Summer, pp. 2-11.

Monden, Y. (1983), Toyota Production System: Practical Approach to Production Management. Third edition. Institute of Industrial Engineers, Atlanta, Georgia.

Monden, Y. (1989), Total cost management system in Japanese automobile corporations, in Monden, Y., and Sakurai, M. (eds), Japanese Management Accounting, Cambridge, MA., Productivity Press, pp. 15-33.

Monden, Y. and Hamada, K. (1991), "Target costing and kaizen costing in Japanese automobile companies." Journal of Management Accounting Research, Vol. 3 No.1, pp. 16-34.

Moormann, M.L. (2014),"How lean are financial service companies really? Empirical evidence from a large scale study in Germany", International Journal of Operations \& Production Management, Vol. 34 No. 11, pp. 1366-1388.

Morgan, J.M. and Liker, J. (2006), The Toyota Product Development System: Integrating People, Process and Technology, Productivity Press, NY.

Moyano-Fuentes, J. and Sacristán-Díaz, M. (2012), "Learning on lean: a review of thinking and research", International Journal of Operations \& Production Management, Vol. 32 No. 5, pp. 551582.

Moyano-Fuentes, J. Sacristán-Díaz, M. and Martínez-Jurado, P.J. (2012), “Cooperation in the supply chain and lean production adoption: Evidence from the Spanish automotive industry", International Journal of Operations \& Production Management, Vol. 32 No. 9, pp. 1075-1096

Nobeoka, K. (1988), Strategy of Japanese Automobile Manufacturers: A Comparison between Honda Motor Co., Ltd. and Mazda Motor Corporation. PhD Thesis, MIT, Massachusetts, Ma.

New, S. (2007), "Celebrating the Enigma: The Continuing Puzzle of the Toyota Production System”, International Journal of Production Research, Vol. 45 No. 16, pp. 3545-3554.

Nishiguchi, T. (1990), Strategic Dualism: An Alternative to Industrial Societies. PhD thesis, University of Oxford, Oxford.

Ohno, T. (1978), Toyota seisan hōshiki, Diamond Inc., Tokyo, Japan.

Ohno, T. (1988), Toyota Production System - Beyond Large Scale Production, English translation copyright, Productivity Press, Portland, OR.

Oliver, N. Delbridge, R. Jones, D. and Lowe, J. (1994), "World Class Manufacturing: Further Evidence in the Lean Production Debate", British Journal of Management, Vol. 5 No. SI. pp. 53-63. 
Oliver, N. and Hunter, G. (1998), "The Financial Impact of 'Japanese' Manufacturing Methods", in Delbridge, R. and Lowe, J. (Eds.), Manufacturing in Transition. Routledge, London, pp. 81-90.

Oliver, N. and Wilkinson, B. (1988), The Japanization of British Industry, Blackwell, Oxford.

Ortman, G. (1995), Formen der Produktion; Organisation und Rekursivitat, Opladen, Westdeutscher Verlag

Panizzolo, R. (1998), “Applying the Lessons Learned from 27 Lean Manufacturers: The Relevance of Relationships Management", International Journal of Production Economics, Vol. 55 No. 3, pp. 223-240.

Papadopoulos, T. and Ozbayrak, M. (2005), "Leanness: Experiences from the Journey to Date", Journal of Manufacturing Technology Management, Vol. 16 No. 7, pp. 784-805.

Pascale, R. (1990), Managing on the Edge, Simon and Schuster, New York, NY.

Pettigrew, A. Woodman, R. and Cameron, K. (2001), "Studying Organizational Change and Development: Challenges for Future Research", Academy of Management Journal, Vol. 44 No. 4, pp. 17-39.

Rich, N. Bateman, N. Esain, A. Massey, L. and Samuel, D. (2006), Lean Evolution: Lessons from the Workplace, Cambridge University Press, Cambridge.

Ries, E. (2011), The Lean Startup: How Constant Innovation Creates Radically Successful Businesses, Penguin, London

Rother, M. (2010), Toyota Kata, McGraw-Hill, NY.

Samuel, D. (2012), Exploring UK lean diffusion in the period 1988 to 2010, PhD Thesis, Cardiff University, Cardiff.

Schmenner, R. and Swink, M. (1998), "On theory in operations management", Journal of Operations Management, Vol. 17 No. 1, pp. 97-113.

Schmenner, R. (2012), Getting and Staying Productive: Applying Swift, Even Flow to Practice, Cambridge University Press, Cambridge.

Schonberger, R. (1996), World Class Manufacturing, Free Press, NY.

Schonberger, R. (2007), "Japanese Production Management: an Evolution - with Mixed Success", Journal of Operations Management, Vol. 25 No. 2, pp. 403-419.

Seddon, J. (2005), Freedom from Command and Control: a better way to make the work work, the Toyota system for service organisations. Second Ed. Vanguard Education Ltd., Buckingham, UK.

Sewell, G. and Wilkinson, B. (1992), "Someone to Watch Over Me: Surveillance, Discipline and the Just-In-Time Labour Process”, Sociology, Vol. 26 No. 2, pp. 271-289.

Shah, R. Goldstein, S. Unger, B. and Henry, T. (2008), "Explaining Anomalous High Performance in a Care Supply Chain”, Decision Sciences, Vol. 39 No. 4, pp. 759-789. 
Shah, R. and Ward, P. (2003), "Lean Manufacturing Context, Practice Bundles and Performance", Journal of Operations Management, Vol. 21 No. 2, pp. 129-149.

Shah, R. and Ward, P. (2007), "Defining and Developing Measures of Lean Production", Journal of Operations Management, Vol. 25 No. 4, pp. 785-805.

Shingo, S. (1989), A Study of the Toyota Production System from an Industrial Engineering Viewpoint, Productivity Press, Portland, Oregon.

Spear, S. (2009), Chasing the Rabbit, McGraw-Hill, NY.

Spear, S. and Bowen, H. (1999), "Decoding the DNA of the Toyota Production System", Harvard Business Review, Vol. Sep-Oct, 97-106.

Standard, C. and Davis, D. (1999), Running Today's Factory: A Proven Strategy for Lean Manufacturing, Society of Manufacturing Engineers, Dearborn, Michigan.

Standard, C. and Davis, D. (2000), "Lean Thinking for Competitive Advantage", Automotive Manufacturing and Production, Vol. 122 No. 12, pp. 68-69.

Stewart, P. (1996), Beyond Japanese Management: The End of Modern Times?, Redwood Books, Trowbridge, Wiltshire.

Sugimoto, Y. (1997), An Introduction to Japanese Society, Cambridge University Press, Massachusetts, Ma.

Sugimori, Y. Kusunoki, K, Cho, F. and Uchikawa, S. (1977), "Toyota production system and Kanban system Materialization of just-in-time and respect-for-human system", International Journal of Production Research, Vol.15 No. 6, pp. 553 - 564.

Swink, M. and Way, M. (1995), "Manufacturing Strategy: Propositions, Current research, Renewed Directions", International Journal of Operations \& Production Management, Vol. 15 No. 7, pp. 4-26.

Tracy, D. and Knight, J. (2008), "Lean Operations Management: Identifying and Bridging the Gap between Theory and Practice”, Journal of American Academy of Business, Vol. 12 No. 2, pp. 8-14.

Turnbull, P. (1986), "The 'Japanization' of Production and Industrial Relations at Lucas Electrical", Industrial Relations Journal, Vol. 17 No. 3, pp. 193-206.

Vokurka, R. and Davis, R. (1996), "Just in time: the evolution of a philosophy", Production and Inventory Management Journal, Vol. 37 No. 2, pp. 56-59.

Voss, C. (1995) "Alternative paradigms for manufacturing strategy", International Journal of Operations \& Production Management, Vol. 15 No. 4, pp.5 - 16

Voss, C. (2005). "Alternative Paradigms for Manufacturing Strategy", International Journal of Operations \& Production Management, Vol. 25 No. 12, pp. 1211-1222.

Ward, A.C. (2007), Lean Product and Process Development, Lean Enterprise Institute Inc., Cambridge, MA 
Wilkinson, B. and Oliver, N. (1989), "Power, Control and the Kanban", Journal of Management Studies, Vol. 26 No. 1, pp. 47-58.

Williams, K. Haslam, C. Williams, J. Culter, A. Adcroft, A. and Johal, S. (1992), "Against Lean Production", Economy and Society, Vol. 21 No. 3, pp. 321-354.

Williams, K. Haslam, C. Johal, S. and Williams, J. (1994), Cars: Analysis, History, Cases. Berghahn Books, Oxford.

Womack, J. (2005), "The Dramatic Spread of Lean Thinking”, Available at www.lean.org. Published as an e-letter $4^{\text {th }}$ November 2005 (accessed on 30th April 2013).

Womack, J. and Jones, D. (1996), Lean Thinking, Simon and Schuster, NY.

Womack, J. and Jones, D. (2005), Lean Solutions, Free Press, NY.

Womack, J. Jones, D. and Roos, D. (1990), The Machine That Changed The World, Rawson Associates, NY.

Wu, Q. (2006), The Impact of Culture on Performance Measurement in the Context of Supply Chain Management: A Systematic Review, Master Dissertation, Cranfield University, Cranfield, UK. 


\begin{tabular}{|l|l|l|}
\hline Lean production & Lean manufacturing & Lean management \\
\hline Lean survive & Lean health & Lean thinking \\
\hline Lean construction & Lean aerospace & Lean defence \\
\hline Lean process & Lean electronics & Lean government \\
\hline Lean education & Lean finance & Lean media \\
\hline
\end{tabular}

Table 1. Key terms used in the formation of the LPD: Source Authors

\begin{tabular}{|c|c|}
\hline Year & Publications/Events \\
\hline 1925 & Frank Woollard publishes "Some Notes on British Methods of Continuous Production" \\
\hline 1932 & Taiichi Ohno joins Toyoda Loom Works as an engineer. \\
\hline 1937 & Toyota Motor Corp. Founded. \\
\hline 1937 & Kiichiro Toyoda visits US, in particular Ford, and begins TPS. \\
\hline 1940 & Training Within Industry programme introduced for US military. \\
\hline $1930-45$ & Ford use flow production to produce bombers at Willow Run. \\
\hline 1948 & W. Edwards Deming first sent to Japan. \\
\hline 1950 & $\begin{array}{l}\text { Labour strikes bring Toyota to near bankruptcy. Kiichiro Toyota resigns and hands over to } \\
\text { cousin Eiji Toyoda who visits Ford River Rouge plant. }\end{array}$ \\
\hline 1954 & Frank Woollard publishes Principles of Mass and Flow Production \\
\hline 1956 & Ohno visits Ford River Rouge plant. \\
\hline 1970s & Business press identifies that Japan's exports are wreaking havoc. \\
\hline 1973 & First oil crisis. \\
\hline 1977 & First English language academic articles on TPS appeared. \\
\hline 1978 & $\begin{array}{l}\text { Ohno publishes Toyota seisan hōshiki (TPS) in Japanese. Vogul publishes Japan as Number 1: } \\
\text { Lessons for America. }\end{array}$ \\
\hline 1979 & Second oil crisis. \\
\hline 1979 & International Motor Vehicle Programme (IMVP) started at MIT. \\
\hline 1979 & $\begin{array}{l}\text { Repetitive Manufacturing Group (RMG) established by the American Production and Control } \\
\text { Society (APICS) and included Schonberger and Hall. }\end{array}$ \\
\hline 1981 & $\begin{array}{l}\text { Monden publishes a series of articles on TPS in Industrial Engineering and Shingo publishes } \\
\text { A Study of Toyota Production System. } \\
\text { Ohno and Kumagi publish a chapter on TPS. } \\
\text { Ouchi publishes Theory Z: How American Business Can Meet the Japanese Challenge. } \\
\text { Pascale and Athos publish The Art of Japanese Management. }\end{array}$ \\
\hline
\end{tabular}




\begin{tabular}{|l|l|}
\hline Year & Publications/Events \\
\hline 1982 & Schonberger publishes Japanese Manufacturing Techniques. \\
\hline 1983 & $\begin{array}{l}\text { Hall publishes Zero Inventories. } \\
\text { Division video } \\
\text { Monden publishes Toyota Production System. }\end{array}$ \\
\hline 1984 & $\begin{array}{l}\text { Toyota enters NUMMI joint venture with GM. } \\
\text { First output of IMVP The Future of the Automobile published. }\end{array}$ \\
\hline 1986 & $\begin{array}{l}\text { The RMG splits from APICS and forms the Association of Manufacturing Excellence (AME) } \\
\text { Krafcik publishes The Triumph of Lean Production and coins the term Lean. } \\
\text { Stalk publishes HBR article, Time: The Next Source of Competitive Advantage, expanding } \\
\text { interest in TPS beyond manufacturing. }\end{array}$ \\
\hline 1990 & \begin{tabular}{l} 
Womack et al., publish The Machine That Changed The World. \\
\hline
\end{tabular} \\
\hline
\end{tabular}

Table 2 Publications and Events leading up to the Emergence of Lean. (Source: compiled from

Holweg, 2007; Shah and Ward, 2007; Schonberger, 2007 and Bicheno and Holweg, 2009)

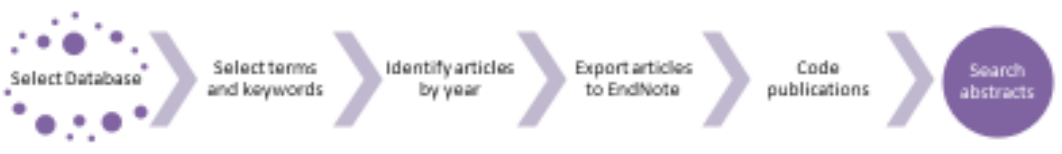




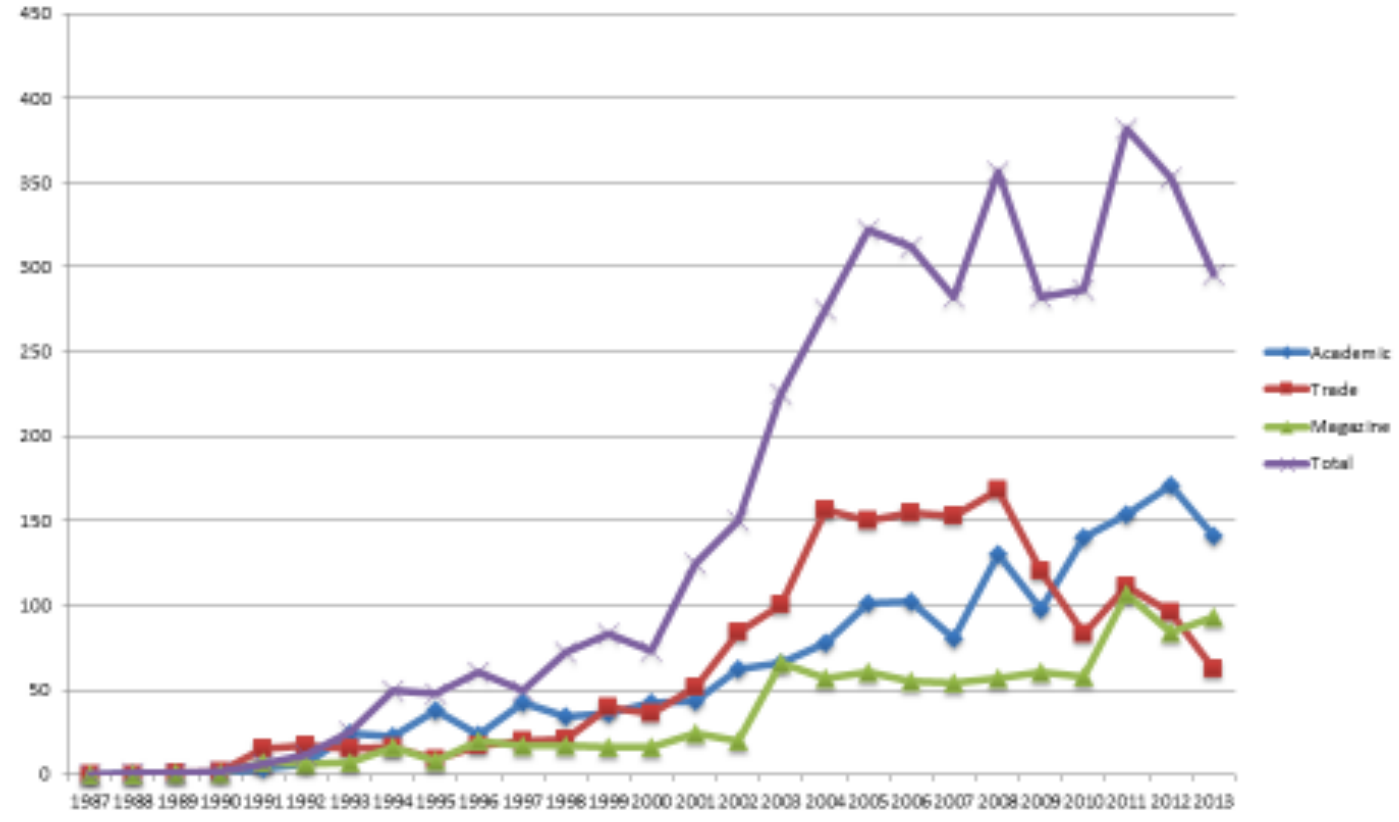

Figure 2. Lean Publieations 1987-2013: Seurce Authers 


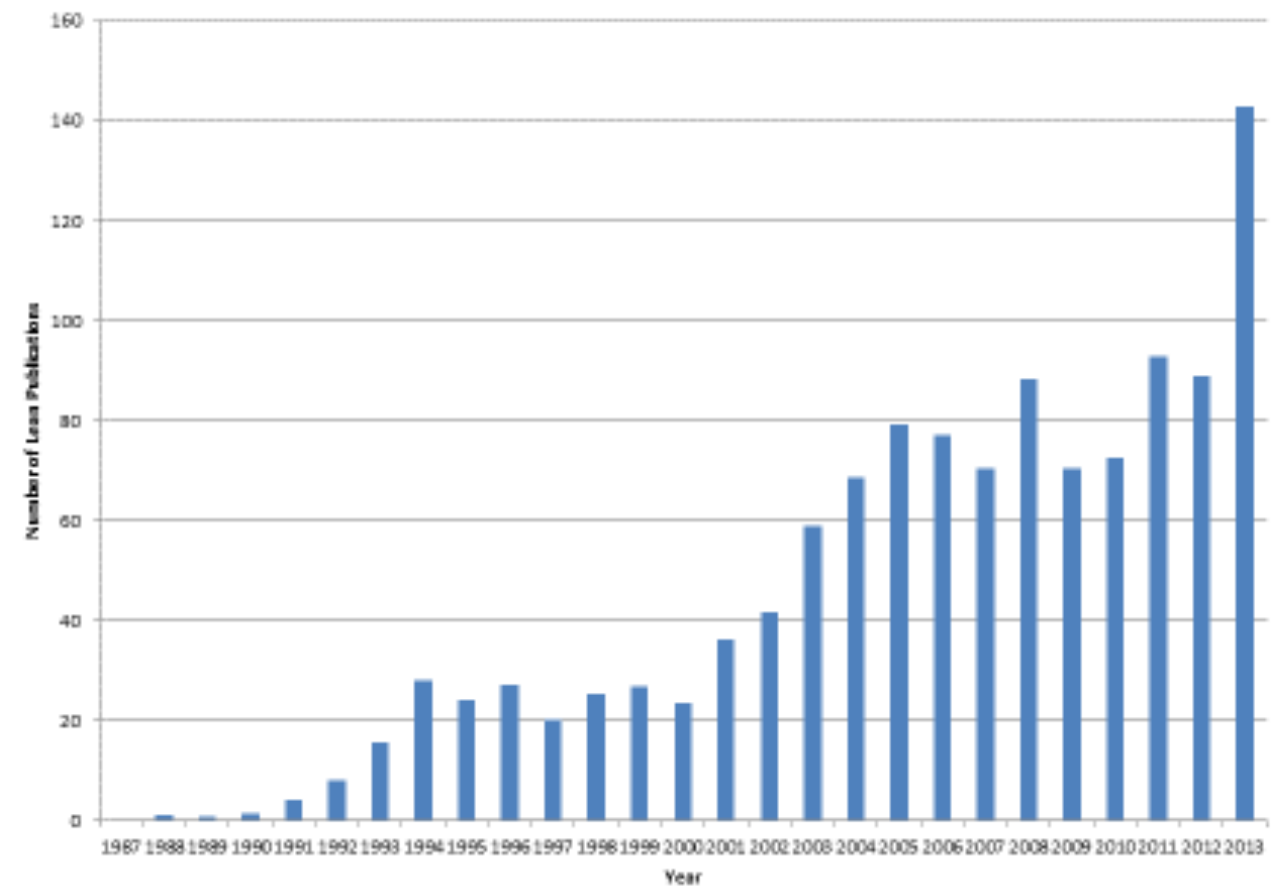

Figure 3. Adjusted number of Lean Publications 1987-2013: Seuree Authers 